\title{
BRIDGING THE GAPS : A PARADIGMATIC INSIGHT INTO PHILOSOPHY OF LAW
}

\author{
Erlyn Indarti \\ Faculty of Law Diponegoro University Semarang \\ erlyn@ymail.com
}

\begin{abstract}
Paradigm represents a worldview that defines, for its holder, the nature of the world, the individual's place in it, and the range of possible relationships to that world and its parts. It comprises of four main elements, i.e. ontology, epistemology, methodology, and methods. Within the discipline of law, there seem to be two sets of gaps separating philosophy of law's building blocks that dissociate, first, legal practice from legal theory and, second, legal science from legal philosophy. It is the purpose of this article, with the help of paradigmatic insight, to bridge those gaps.
\end{abstract}

Keywords: law, philosophy of law, paradigm, paradigmatic study of law

\section{Introduction}

Driven by the desire to fulfill their curiosity to understand the reality of life around them, as well as the fighting spirit to meet the ever-changing needs, humans are required to develop their knowledge. In making the effort to develop knowledge and to anticipate the process of change, humans need to construct new foundation of thought so as to enrich the existing treasury of scientific disciplines. This is when research inquiries are called for. ${ }^{1}$ In this regard, one field of inquiry that is worth exploring is philosophy, especially philosophy of law.

The linkage between philosophy and philosophy of law can be traced back to one mode of arrangement that divides philosophy into three categories, namely systematic philosophy, special philosophy and scientific philosophy. In this case,

1 Sudarto. Metodologi Penelitian Filsafat (Jakarta : PT RajaGrafindo Persada, 1997). 
philosophy of law, together with philosophy of culture, philosophy of education, philosophy of politics and philosophy of religion, is included within special philosophy. ${ }^{2}$ Other taxonomy classifies philosophy into eleven areas, such as philosophy of politics, philosophy of religion, philosophy of science, philosophy of education, and philosophy of law. ${ }^{3}$ Because law is perceived to be related to norms that regulate human behavior, it is understandable if still other categorization incorporate philosophy of law into what is called philosophy of behavior, which is part of human philosophy. ${ }^{4}$ Thus, observed from whichever point of view, relation between philosophy and philosophy of law, as represented by these classifications, is real: philosophy of law is part of philosophy rather than law.

It should be noted that there is a terminological difference between 'philosophy of law' and 'legal philosophy'. Despite the fact that they both deal with philosophy and law, their area of study is actually dissimilar. As indicated earlier philosophy of law is a part of philosophy, and for that reason copes first and foremost with philosophy. Legal philosophy is a subject in law, and therefore concerns itself firstly with law. In other words, their operational base is different philosophy of law is within philosophy, whereas legal philosophy is within the legal academy. Additionally, due to the difference in their field of emphasis, philosophy of law appears to be broader than legal philosophy. ${ }^{5}$ It can be said, with its wide ranging coverage, philosophy of law is actually legal philosophy in a broader sense.

As it has previously been mentioned, the development of knowledge basically requires research activities. Through these activities issues under reviewed are expected to be better formulated, research questions can be more carefully prepared, and answers to the questions can be more precisely delivered.

2 T. L. Gie. Suatu Konsepsi ke Arah Penertiban Bidang Filsafat (Yogyakarta : Karya Kencana, 1977).

3 J. S. Suriasumantri. Filsafat Ilmu : Sebuah Pengantar Populer (Jakarta : Sinar Harapan, 1985).

4 D. Darmodiharjo dan Shidarta. Pokok-Pokok Filsafat Hukum (Jakarta : Gramedia Pustaka Utama, 1999).

5 "Law, Politics, and Philosophy", Philosophy of Law, https://tamayaosbc.wordpress.com (August 17, 2014). 
Without research inquiries, fields of studies in general, including philosophy of law in particular, seems to be 'going nowhere'. On the other hand, with disciplined inquiries, horizon of knowledge can be further expanded, present knowledge can be meticulously modified, and future knowledge can be thoroughly pursued. All of this is intended to facilitate safety in surfing the everchanging era which may, in some way, destabilize all aspects of life.

One way to set up new foundation of thought is through the adoption of paradigmatic analysis into the realm of philosophy, including philosophy of law. It was Thomas Kuhn, a theorist of physics, who first introduced the term 'paradigm' to science in the first years of the $60 \mathrm{~s}$. Paradigm can be understood as a disciplinary matrix, that can be considered as a kind of base point, from which the venture of scientific disciplines is begun and is expected to continue to flow. ${ }^{6}$ Paradigm may also be refered to as the consensual set of beliefs and practices that guide a field of study. It should be underlined that, although paradigm has become a central concept in social science research methodology, its meaning is rather different from the way that term is used in the field of science studies. ${ }^{7}$

In relation to philosophy in general, there are some observers questioning the difference between theory and practice. ${ }^{8}$ Others recognize the discrepancy between philosophy and science. ${ }^{9}$ There also seems to be certain gaps separating philosophy of law's building blocks, i.e. legal theory, legal practice, legal philosophy, and legal science. It is the purpose of this article, with the help of paradigmatic insight, to bridge those gaps.

\section{Research Methods}

6 T. S. Kuhn. The Structure of Scientific Revolutions (Chicago: The University of Chicago Press, 1962).

7 D. L. Morgan, "Paradigms Lost and Pragmatism Regained - Methodological Implications of Combining Qualitative and Quantitative Methods," Journal of Mixed Methods Research 1, no. 1 (January 2007).

8 "Theory and Practice", Boundless, Boundless Sociology, https://www.boundless.com (August 08, 2016).

9 "What is the Difference Between Science and Philosophy", Quora, https://www.quora.com (April 14, 2013; March 18, 2014; July 8 and 16, 2014) 
Applying the conventions of philosophical research method, this article analytically traces the common thread between paradigm and philosophy of law by means of literature review. This choice of philosophical research method is due to the fact that philosophy of law is basically part of philosophy. With such method, the philosophycal vision of the elements of paradigm can be tracked down; at the same time, the contour of the building blocks of philosophy of law can be outlined. This would eventually contribute to the achievement of comprehensive understanding of the integrated interwoven strands of paradigm and philosophy of law.

\section{Result and Discussion}

\subsection{Paradigm and Philosophy of Law: Interwoven into the Tips}

\section{What is a Paradigm?}

Stated briefly, a paradigm is "the set of common beliefs and agreements shared between scientists about how problems should be understood and addressed". ${ }^{10}$ Elaborated further, a paradigm may be viewed as a set of basic beliefs (or metaphysics) that deals with ultimates or first principles. It represents a worldview that defines, for its holder, the nature of the "world, "the individual's place in it, and the range of possible relationships to that world and its parts. Inquiry paradigms define for inquirers what it is they are about, and what falls within and outside the limits of legitimate inquiry. The basic beliefs that define inquiry paradigms can be summarized by the responses given by proponents of any given paradigm to three fundamental questions, which are interconnected in such a way that the answer given to anyone question, taken in any order, constrains how the others may be answered: ${ }^{11}$

a. The ontological question: what is the form and nature of reality and, therefore, what is there that can be known about it?

10 T. S. Kuhn. 1962.

11 E.G. Guba and Y.S. Lincoln, 'Competing paradigm in qualitative research', in N.K. Denzin dan Y.S. Lincoln, Handbook of Qualitative Research (London: Sage Publications, 1994). 
b. The epistemological question: what is the nature of the relationship between the knower or would-be knower and what can be known?

c. The methodological question: how can the inquirer (would-be knower) go about finding out whatever he or she believes can be known?

Equipped with these questions, Lincoln, Lynham, and Guba were able to come up with five paradigms, namely positivism, post-positivism, critical theory et.al., constructivism, and participatory. ${ }^{12}$ Table 1 shows basic beliefs of those alternative inquiry paradigms.

Tabel 1. Basic Beliefs of Alternative Inquiry Paradigms

\begin{tabular}{|c|c|c|c|c|c|}
\hline Issue & Positivism & Postpositivism & Critical Theory & $\begin{array}{c}\text { Constructivis } \\
m\end{array}$ & $\begin{array}{c}\text { Participator } \\
y\end{array}$ \\
\hline Ontology & $\begin{array}{l}\text { Naive realism: } \\
\text { "real" reality but } \\
\text { apprehendible }\end{array}$ & $\begin{array}{l}\text { Critical realism: } \\
\text { "real" reality but } \\
\text { only imperfectly } \\
\text { and } \\
\text { probabilistically } \\
\text { apprehendible }\end{array}$ & $\begin{array}{l}\text { Historical } \\
\text { realism: } \\
\text { virtual reality } \\
\text { shaped by social, } \\
\text { political, cultural, } \\
\text { economic, ethnic, } \\
\text { and gender } \\
\text { values: } \\
\text { crystallized over } \\
\text { time }\end{array}$ & $\begin{array}{l}\text { Relativism: } \\
\text { local and } \\
\text { specific co- } \\
\text { constructed } \\
\text { realities }\end{array}$ & $\begin{array}{l}\text { Participative } \\
\text { reality: } \\
\text { subjective } \\
\text { objective } \\
\text { reality, co- } \\
\text { created by } \\
\text { mind and } \\
\text { given cosmos }\end{array}$ \\
\hline $\begin{array}{c}\text { Epistemolog } \\
\mathrm{y}\end{array}$ & $\begin{array}{l}\text { Dualist/ } \\
\text { objectivist; } \\
\text { findings true }\end{array}$ & $\begin{array}{l}\text { Modified dualist/ } \\
\text { objectivist; } \\
\text { critical tradition/ } \\
\text { community; } \\
\text { findings probably } \\
\text { true }\end{array}$ & $\begin{array}{l}\text { Transactional/ } \\
\text { subjectivist; } \\
\text { value-mediated } \\
\text { findings }\end{array}$ & $\begin{array}{l}\text { Transactional/ } \\
\text { subjectivist; co- } \\
\text { created } \\
\text { findings }\end{array}$ & $\begin{array}{l}\text { Critical } \\
\text { subjectivity in } \\
\text { participatory } \\
\text { transaction } \\
\text { with cosmos; } \\
\text { extended } \\
\text { epistemology } \\
\text { of } \\
\text { experiential, } \\
\text { propositional, } \\
\text { and practical } \\
\text { knowing; co- } \\
\text { created } \\
\text { findings }\end{array}$ \\
\hline $\begin{array}{c}\text { Methodolog } \\
\mathrm{y}\end{array}$ & $\begin{array}{l}\text { Experimental/ } \\
\text { manipulative; } \\
\text { verification of } \\
\text { hypothesis; chiefly } \\
\text { quantitative }\end{array}$ & $\begin{array}{l}\text { Modified } \\
\text { experimental/man } \\
\text { ipulative; critical } \\
\text { multiplism; } \\
\text { falsification of }\end{array}$ & $\begin{array}{l}\text { Dialogic/ } \\
\text { dialectical }\end{array}$ & $\begin{array}{l}\text { Hermeneutical/ } \\
\text { dialectical }\end{array}$ & $\begin{array}{l}\text { Political } \\
\text { participation } \\
\text { in } \\
\text { collaborative } \\
\text { action }\end{array}$ \\
\hline
\end{tabular}

12 Y. S. Lincoln, S. A. Lynham, and E. G. Guba, "Paradigmatic Controversies, Contradictions, and Emerging Confluences, Revisited", in N. K. Denzin and Y. S. Lincoln (Eds.), The Sage Handbook of Qualitative Research (London: Sage Publications, 2011). 


\begin{tabular}{|l|l|l|l|l|}
\hline methods & $\begin{array}{l}\text { hypothesis; may } \\
\text { include } \\
\text { qualitative } \\
\text { methods }\end{array}$ & & $\begin{array}{l}\text { inquiry; } \\
\text { primacy of } \\
\text { the practical; } \\
\text { use of } \\
\text { language } \\
\text { grounded in } \\
\text { shared } \\
\text { experiential } \\
\text { context }\end{array}$ \\
\hline
\end{tabular}

Source: Y. S. Lincoln, S. A. Lynham, and E. G. Guba (2011)

When the above features applied into the field of law, as far as ontological issue is concerned, positivism, with its naive realism, understands law as real reality but apprehendible. Postpositivism, through critical realism, recognizes law as real reality but only imperfectly and probabilistically apprehendible. Critical theory, driven by historical realism, comprehends law as virtual reality shaped by social, political, cultural, economic, ethnic, and gender values: crystallized over time. Constructivism meanwhile, imbued with relativism, perceives law as local and specific co-constructed realities. Finally, participatory, enriched with its participative reality, observes law as subjective - objective reality, co-created by mind and the existing complex orderly system, such as social, political, economic, cultural, and legal system.

In terms of epistemology, positivism holds a dualist and objectivist view about the relation between the observer and the observed, i.e. law. Positivism also acknowledges that the findings extracted from inquiries into legal matters are true. As for postpositivism, it embraces a modified dualist and objectivist stand on the relation between the inquirer and law. It critically questions the conformity between legal research findings and the existing legal knowledge. Postpositivism has its doubts whether the findings of legal inquiry are true. Citical theory, meanwhile, adopts a transactional/subjectivist position on the link between the researcher and law. It perceives value-mediated nature of the results of legal research. Similar to critical theory's position, constructivism also has a transactional/subjectivist view toward the observer-observed, i.e. law, relation. However, it maintains that the outcomes of the legal inquiry are co-created. Lastly, 
participatory takes on critical subjectivity view and holds that the researcher and law are in a participatory transaction, between them as well as with the prevailing ordered system. It assumes extended epistemology of experiential, propositional, and practical knowing of law. Much like constructivism, participatory is also of the opinion that the results of legal research are actually co-created findings.

In regard to methodological issue, positivism applies experimental and manipulative way of doing research into law. Positivist research rests on mainly verification of hypothesis and chiefly quantitative methods. Postpositivism exercises modified experimental and manipulative methodology to investigate law. In doing so, it cautiously employs multiple methods, including qualitative methods. Instead of verification, postpositivism relies on falsification of hypothesis. As for critical theory, it uses dialogic/dialectical methodology to look into legal questions. Shifting a away from critical theory, in order to examine legal matters, constructivism draws on hermeneutical/dialectical methodology. Lastly, so as to examine legal issues, participatory turns to collaborative action research and focuses on political participation. In this genre of methodology, use of language is grounded in shared experiential context and primacy of the practical is promoted.

Looking into the above table more thoroughly, one would have no difficulty in identifying the term 'methods' incorporated within the methodology row. Since 'method' is in fact the elaboration of 'methodology', it may well be considered as the fourth issue of the alternative inquiry paradigms. Taking ontology as the core of the sphere of paradigmatic concept, and each issue as the layer constructing the sphere, then the issue of method may be seen as the outermost layer of the sphere. The link among ontology, epistemology, methodology, and method, together with theoretical perspective in between and sources at the end, is shown in the following picture. $^{13}$

\section{Figure 1. From Ontology to Sources}

13 S. Patel, "Methodology, Epistemology, and Ontology Explained in Simple Language," http://salmapatel.co.uk/academia/the-research-paradigm, (July, 2015). 


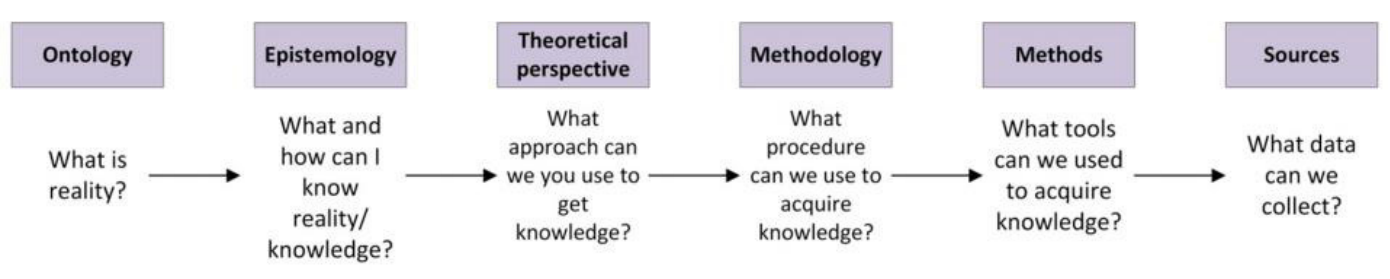

Source: S. Patel. 2015

For the purpose of the current writing, theoretical perspective and sources are omitted, leaving the relationship to incorporate ontology, epistemology, methodology, and method. Picture 2, below, shows such relationship. 


\section{Figure 2. Ontology-Epistemology-Methodology-Method}

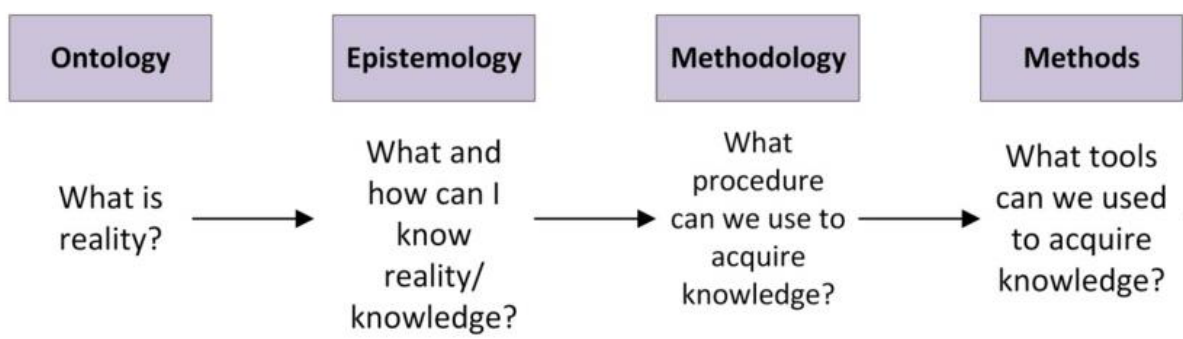

\section{Philosophy of Law: An Omnibus Vehicle for Legal Inquiries}

It has been indicated above that philosophy, in broader sense, concerns with, among other things, practice, theory, science, and philosophy itself, in its narrow sense. In terms of philosophy of law, this would mean legal practice, legal theory, legal science, and legal philosophy. Nevertheless, how these ingredients of philosphy relate to each other and how they are arranged in such a way that make knowledge development possible, are still in question.

To start with, the practice of law involves giving legal advice to clients, drafting legal documents for clients, and representing clients in legal negotiations and court proceedings such as lawsuits, and is applied to the professional services of a lawyer or attorney at law, barrister, solicitor, or civil law notary. ${ }^{14}$ But the term 'practice' basically conveys wider understanding. With regard to law, legal practice is the observation of disparate concepts of law that needs explanation. In general, legal practice refers to the actual observation, operation, or experiment of law. In legal practice, an empirical approach may be utilized that seeks to understand what is going on with law in the social world and how it happens. Legal practice, or legal empirical analysis, cannot stand on its own without underlying theoretical questions (the why) that guide the legal research ${ }^{15}$

So as to better understand legal theory, one should not assume that there is a single yes or no answer to the questions surrounding the relevance of legal

14 https://en.wikipedia.org/wiki/Practice_of_law/

$15 \mathrm{https} / / / \mathrm{www} \cdot$ boundless.com 
theory.or treat legal theory and legal practice as discrete, unrelated entities. Legal theory is certainly relevant to legal practice. In fact, the constitutionalization, transnationalization, and Europeanization of legal systems are changing the practice of law in a way that is more congenial to theory than hitherto. In regard to this, legal roles embodying a legislative standpoint within law are creating a demand for increased theoretical sophistication. So, there should be no reserve to acknowledge legal theory as part of the academic legal curriculum ${ }^{16}$

Applying the understanding of theory to law, a legal theory can be perceived as a proposed relationship between two or more observed legal phenomena. Legal theory can also be comprehended as a coherent statement or set of ideas that explains observed legal facts or phenomena, or which sets out the principles of law which is known or observed. A legal theory is therefore a proposed explanation of the relationship between two or more legal concepts, or an explanation for how/why a legal phenomenon occurs. ${ }^{17}$

Although in 'theory' there is no difference between theory and practice. In 'practice', the difference are admitted. This is a question of thinking and hitting at the same time. At law school, there is in fact a daily acknowledgement of the differences between theory and practice and between thinking and doing. Constant effort to bridge the two is therefore needed, because in this creative tension between theory and practice lies the comparative advantage. ${ }^{18}$

In the meantime, as it is commonly acknowledged, legal philosophy it is the quest for the most general truths about law. On the other hand, legal science is the study of the consistent, observable features of law. That is, it's about observing that law appears to follow certain patterns, trying to induce what those patterns are, and continually improving the understanding of those patterns to make them more and more reliable. ${ }^{19}$ In brief, legal science is perceived as the study of empirically

16 G. V. Villaca, "Why Teach Legal Theory Today," German Law Journal, 16 no. 04 (2015).

17 Ibid.

18 "Theory and Practice, at the Same Time". Harvard Law Today. http://today.law.harvard.edu/letter-from-the-dean/theory-and-practice-at-the-same-time.

19 Quora, https://www.quora.com/What-is-the-difference-between-science-and-philosophy. 
testable propositions of law. At first glance, there seems to be something in the definition that causes the domains of these two disciplines to be exclusively separated. Observing in detail, though, in turns out that the idea that legal science cannot or should not address the questions of legal philosophy (and vice versa) is based on a false dichotomy. ${ }^{20}$

Legal science is also recognized as a strategy for arriving at consensus answers to questions about law. It focuses on discovering "facts", "laws", and "mechanisms" of law. Often what are discovered are new objects that were previously unseen and unknown to exist. In contrast, legal philosophy frames the questions and sets the rules of debate on law. It does this by exploring the landscape of what might be true about law and figuring out how different approaches to legal truth interrelate. The dialog of legal philosophy focuses on logic, rules of argumentation, and the definition of abstract concepts of law. The approach and practice of legal science, including the "legal scientific method" arose out of legal philosophy. ${ }^{21}$

Meanwhile, echoing in many parts of the world, outcries for basis for distinguishing between science and non-science in law are heard. They ask for reformed perceptions of law and legal education that distinguish between law as a science and law as vocational legal training. The practice of the "science of law" would require that students distil the general and fundamental principles of law from decided cases, which are seen as the "dataset" of the science, by using inductive reasoning. ${ }^{22}$ At this point, it could be noticed, besides legal philosophy, apparently legal science relates to legal practice as well.

Both sets of discussions as briefly outlined above are actually about the gaps that dissociate, first, legal practice from legal theory and, second, legal science from legal philosophy. Interestingly, at the same time, the discussions also testify to the consciousness of the attempt to bridge the disparities. But, no matter how

\footnotetext{
Ibid.

Quora, https://www.quora.com/What-is-the-relationship-between-science-and-philosophy.

M. C. Roos, "Is Law Science?", Potchefstroom Electronic Law Journal, 17 no. 4 (2014).
} 
hard the effort is made to do so, the connection never seems to be completed. It is as if there were something invincible lying down in between, and thus separating, them. This is when the idea of superimposing the two pairs of disparities, i.e. legal practice - theory and legal science - legal philosophy, come into being. Only then can it be realized that there lies legal science between legal practice and legal theory as well as legal theory between legal science and legal philosophy. So, this is more than just bridging the gap between legal practice and legal theory or between legal science and legal philosophy. This is about bridging the gaps all the way, from legal practice, go by legal science, slip by legal theory, and finally up to legal philosophy. Once the gaps are connected, what is constructed is a complete and harmonious whole of philosophy of law. This is a kind of omnibus of philosophy of law consisting of building blocks that systematically flow from legal philosophy, pass legal theory, through legal science, and down to legal practice. Picture 3 below depicts this idea.

Figure 3. A Complete and Harmonious Whole of Philosophy of Law

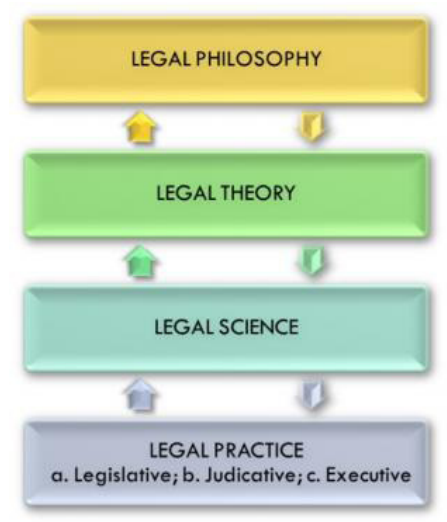




\subsection{Paradigmatic Study of Law: Probing into the Wholeness of Philosophy of Law}

What paradigm is and how it incorporates interrelated ontology, epistemology, methodology, and method of legal research, have been discussed above. Picture 2 describes this relationship. How philosophy of law performs as an omnibus vehicle for legal inquiries, consisting of legal philosophy, legal theory, legal science, and legal practice, has also been analyzed. Picture 3 portrays such wholeness. Incorporating Picture 2 and Picture 3, while at same time merging the two sets of discussions elucidating each understanding of both pictures, an amalgamation of mental construction of paradigm and philosophy of law can therefore be drawn. Picture 4 below exposes this fusion.

\section{Figure 4. Paradigm and Philosophy of Law: One On One Integration}

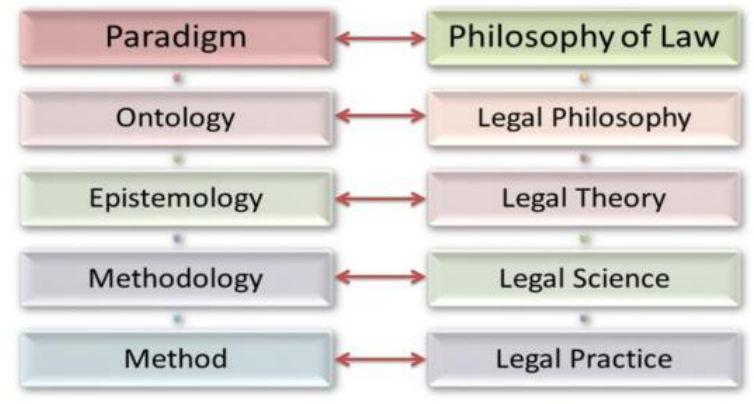

As the elements of paradigm systematically stream down from ontology, followed by epistemology, afterwards methodology, and then down to method, so do the building blocks of philosophy of law, from legal philosophy, thereafter legal theory, next legal science, and after that down to legal practice. This parallel sequencing of ingredients brings through one on one integration among the elements of paradigm and the building blocks of philosophy of law. Thus, within the discipline of law, having a conversation about paradigm is fundamentally exchanging views on the buiding blocks of philosophy of law -i.e. legal philosophy, legal theory, legal science, and legal practice- and vice versa. 
In light of the above discussion, a preliminary concept of paradigmatic study of law can then be outlined. Armed with ontological, epistemological, methodological, and methodical questions, paradigmatic study of law probes into the wholeness of philosophy of law. Its investigation coverage extents from legal philosophy, pass legal theory, through legal science, and down to legal practice. The study may not need to go deeply into each and every building block of philosophy of law, but it values highly the integrity, continuity, as well as accountability of the flow of legal logical reasoning, from ontology/legal philosophy down to method/legal practice. It can be broadly expressed that paradigmatic study of law is like a vehicle well equipped for legal inquiries.

\section{Conclusion}

One way to set up new foundation of thought for developing knowledge is through the adoption of paradigmatic analysis into the realm of philosophy, including philosophy of law. Paradigm may be viewed as a set of basic beliefs (or metaphysics) that deals with ultimates or first principles. It represents a worldview that defines, for its holder, the nature of the world, the individual's place in it, and the range of possible relationships to that world and its parts. Inquiry paradigms define for inquirers what it is they are about, and what falls within and outside the limits of legitimate inquiry.

Paradigms comprises of four main elements, ontology which questions what reality is, epistemology which enquires about what one can know about the reality or knowledge, methodology which deals with what kind of procedure one can use to acquire knowledge, and methods which asks for what tools one can use to gain knowledge. Coupling with these four elements are five main paradigms widely accepted within the field of social inquiry, namely positivism, postpositivism, critical theory, constructivism, and participatory.

Within the discipline of law, there seems to be two sets of gaps separating philosophy of law's building blocks, first, legal practice from legal theory, and second, legal science from legal philosophy. Unfortunately, the consciousness of the attempt to bridge the disparities is somehow equally countered with the 
acknowledgment of the gaps that dissociate, first, legal practice from legal theory and, second, legal science from legal philosophy. This is when the idea of superimposing the two pairs of disparities in order to bridge the gaps is proposed. The result is an omnibus of philosophy of law consisting of building blocks that systematically flow from legal philosophy, legal theory, legal science, and down to legal practice.

As the elements of paradigm systematically stream down from ontology, epistemology, methodology, and down to method, so do the building blocks of philosophy of law, from legal philosophy, legal theory, legal science, and then legal practice. This corresponding succession leads to one on one integration among the elements of paradigm and the building blocks of philosophy of law. This is when the idea of paradigmatic study of law is put forward. Making the best use of ontological, epistemological, methodological, and methodical questions, the study looks into the integrity, continuity, as well as accountability of the flow of legal logical reasoning, from ontology/legal philosophy down to method/legal practice.

\section{References}

Darmodiharjo, D. dan Shidarta. (1999). Pokok-Pokok Filsafat Hukum. Jakarta: Gramedia Pustaka Utama.

Gie, T. L. (1977). Suatu Konsepsi ke Arah Penertiban Bidang Filsafat. Yogyakarta : Karya Kencana.

Guba, E. G. and Lincoln, Y. S. (1994). "Competing paradigm in qualitative research," in Denzin, N. K. and Lincoln, Y. S. Handbook of Qualitative Research. London: Sage Publications.

Kuhn, T. S. (1962). The Structure of Scientific Revolutions. Chicago: The University of Chicago Press.

Lincoln, Y. S., Lynham, S. A., and Guba, E. G. (2011). "Paradigmatic Controversies, Contradictions, and Emerging Confluences, Revisited", in Denzin, N. K. and Lincoln, Y. S. (Eds.). The Sage Handbook of Qualitative Research. London: Sage Publications. 
Morgan, D. L. "Paradigms Lost and Pragmatism Regained - Methodological Implications of Combining Qualitative and Quantitative Methods," Journal of Mixed Methods Research 1, no. 1 (January 2007).

Roos, M. C. (2014). Is Law Science?. Potchefstroom Electronic Law Journal, 17(04).

Patel, S. (2015). "Methodology, Epistemology, and Ontology Explained in Simple Language," http://salmapatel.co.uk/academia/the-research-paradigm.

Sudarto. (1997). Metodologi Penelitian Filsafat. Jakarta : PT RajaGrafindo Persada.

Suriasumantri, J. S. (1985). Filsafat Ilmu : Sebuah Pengantar Populer. Jakarta : Sinar Harapan.

Villaca, G. V. (2015). Why Teach Legal Theory Today. German Law Journal, 16(04).

"Law, Politics, and Philosophy", Philosophy of Law, https://tamayaosbc.wordpress.com (August 17, 2014).

"Theory and Practice", Boundless, Boundless Sociology, https://www.boundless.com (August 08, 2016).

"Theory and Practice, at the Same Time". Harvard Law Today. http://today.law.harvard.edu/letter-from-the-dean/theory-and-practice-at-thesame-time.

"What is the Difference Between Science and Philosophy", Quora, https://www.quora.com (April 14, 2013; March 18, 2014; July 8 and 16, 2014)

Quora,https://www.quora.com/What-is-the-difference-between-science-andphilosophy.

Quora,https://www.quora.com/What-is-the-relationship-between-science-andphilosophy.

https://en.wikipedia.org/wiki/Practice_of_law/ 